\title{
PATHWAYS TO INDIGENOUS IDENTITY: ONE FAMILY'S STORY OF COLONIZATION AND REINTEGRATION
}

\author{
by \\ Shanna Giroux, BSW, Renison University College, 2012
}

\begin{abstract}
An MRP
presented to Ryerson University
\end{abstract}

in partial fulfillment of the

requirements for the degree of

Master of Social Work

in the Program of

Social Work

Toronto, Ontario, Canada, 2017

(C) Shanna Giroux 2017 


\section{AUTHOR'S DECLARATION FOR ELECTRONIC SUBMISSION OF A MRP}

I hereby declare that I am the sole author of this MRP. This is a true copy of the MRP, including any required final revisions.

I authorize Ryerson University to lend this MRP to other institutions or individuals for the purpose of scholarly research

I further authorize Ryerson University to reproduce this MRP by photocopying or by other means, in total or in part, at the request of other institutions or individuals for the purpose of scholarly research.

I understand that my MRP may be made electronically available to the public. 


\begin{abstract}
Pathways to Indigenous Identity: One Family’s Story of Colonization and Reintegration Master of Social Work, 2017 Shanna Giroux Masters of Social Work, Ryerson University
\end{abstract}

This research study is an examination of one family's journey of finding out about their Indigenous ancestry later in life and how, if at all, it has affected their sense of identity or feelings of interest in engaging with the Indigenous communities of Canada. In cooperation with her father, the principal researcher uses an Indigenous research method of storytelling and a methodology based on medicine wheel teachings to discuss their learning about their Indigenous heritage as adults with little to no connections to their original community. Through storytelling, the research study hopes to reveal the complications of forming an Indigenous identity later in life and after generations of colonization have erased familial traditions and knowledge. 


\section{ACKNOWLEDGEMENTS}

To my dad, for demonstrating all the grandfather teachings and walking down this path with me

To my mom, for walking along side of us in our journey

To my uncle, for including me in your story before I knew my own

To Joanne, for introducing me to myself 


\section{DEDICATION}

To my ancestors,

For all the times you were made to feel less than

For all the times you were silenced

For all the times you were erased

This is for you

It's a time to be proud

It's a time to speak our truth

It's a time to be reborn 


\section{TABLE OF CONTENTS}

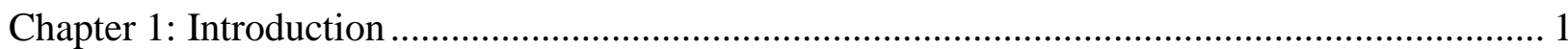

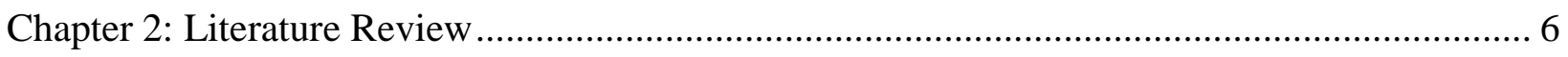

Colonial/White Identification Systems for Indigenous Peoples ................................................ 7

Shared Indigenous Definitions of Belonging/Identity …………............................................ 9

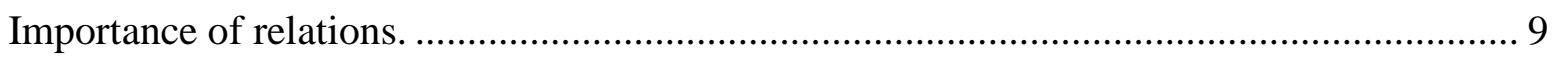

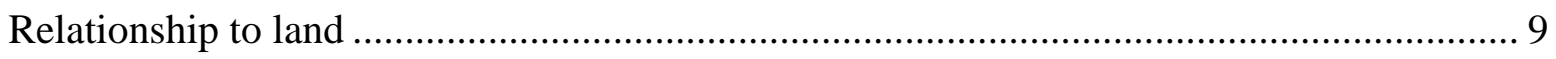

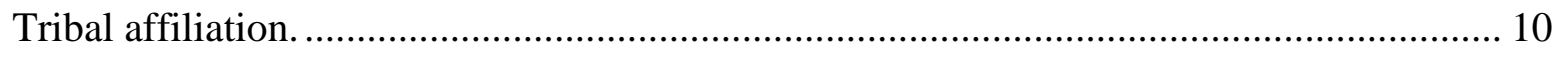

Métis Identification and Belonging .................................................................................. 11

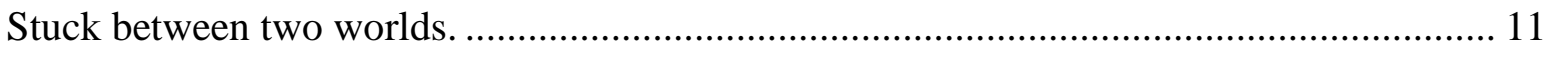

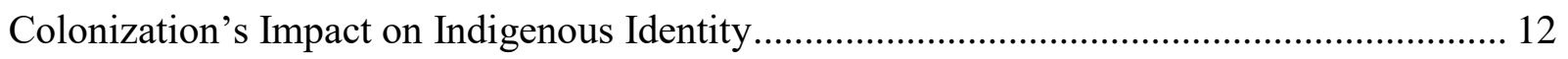

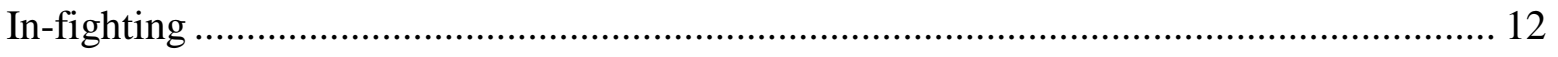

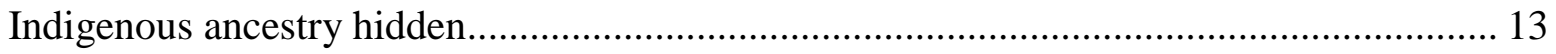

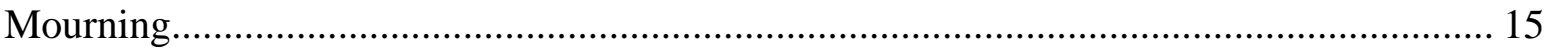

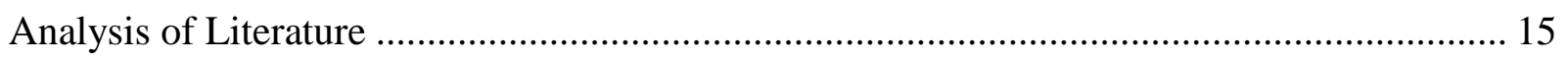

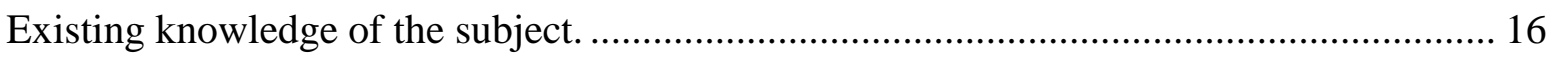

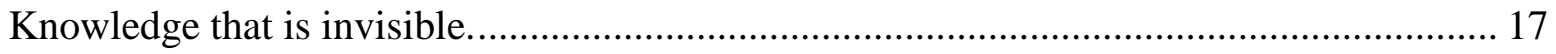

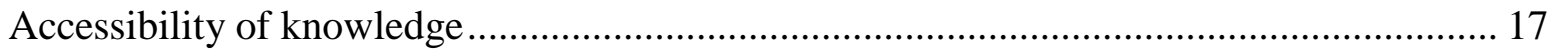

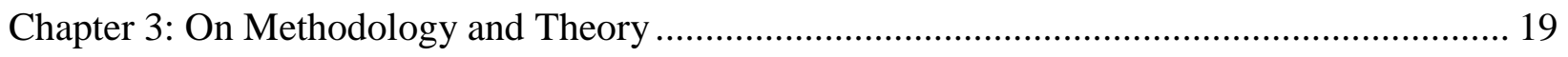


Indigenous Ways of Knowing

Method 25

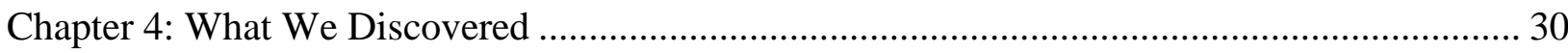

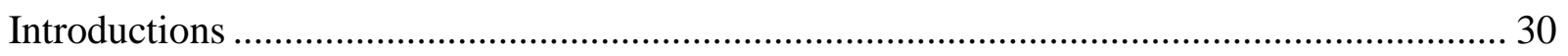

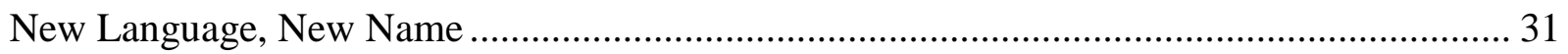

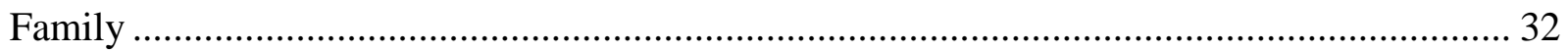

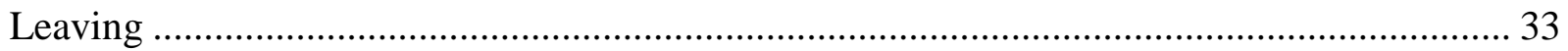

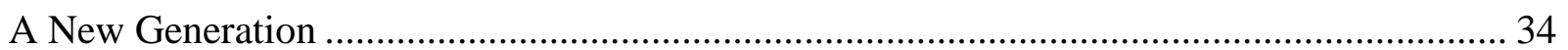

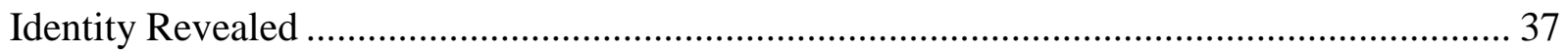

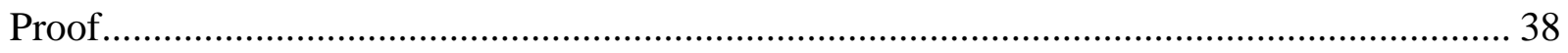

School/Community/Elder Support................................................................................... 39

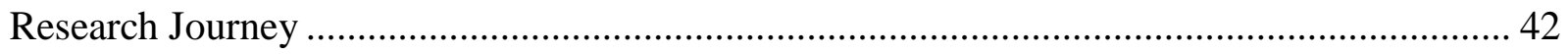

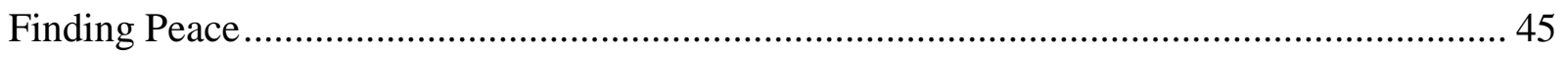

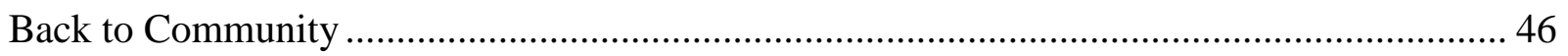

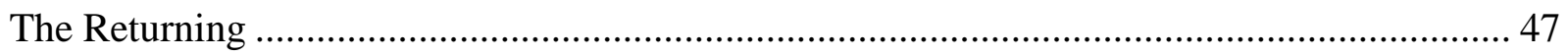

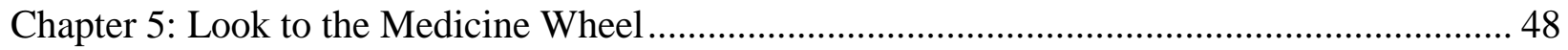

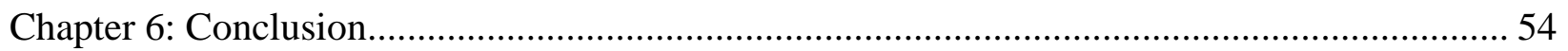

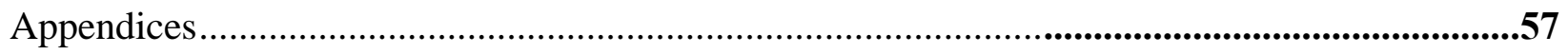

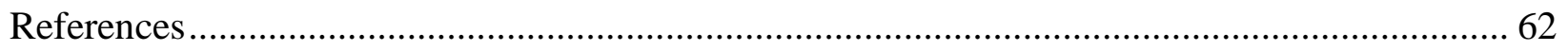




\section{LIST OF APPENDICES}

Appendix A - Consent Form for Participant

Page \#57 


\section{Chapter 1: Introduction}

Being an Indigenous person in Canada is a complicated matter. Depending on who you're speaking to, if you identify as an Indigenous person, you'll be met by questions with an undertone of disbelief and doubt of your heritage. There is a long history as to why this happens and my hope is that I can begin to explore some of this history from my own current understandings of Indigenous identity formation and how it relates to centuries of colonization. I learned when I was in my early thirties that I have Indigenous heritage. This was the first time it had ever actually been confirmed for me. I remember my dad once telling me that we have Native relatives "somewhere back there" and that was the end of the conversation. But now, we had certifiable, traceable ancestry. We've done some work and sought some answers and I'd like to share my story with you.

Before we begin, I'd like to introduce myself to you, the reader, as this is custom in the spirit of Indigenous relationality. My name is Shanna Giroux and I am a descendent of Algonquin Peoples. I am a non-status member of the Bonnechere Algonquin First Nation (BAFN) in Renfrew, Ontario though I've never stepped foot on the land. I am golden eagle clan, which means that my role in my community is that of a spiritual leader. I have a spirit name but was instructed by an Indigenous Elder that this is only for me to know as well as a very few close family and friends. I was born in Thunder Bay, Ontario and raised in London, Ontario, currently residing in Toronto. I am new to the Indigenous community.

When I first found out about my heritage I was excited, but it quickly turned to apprehension. Do I have a right to identify as an Indigenous woman having been so far removed from the community for so long? If I did engage in the pan-Indigenous community of Toronto was I just appropriating culture and acting as a colonizer? I did an awful lot of reflecting about it 
and then became paralyzed by my fear and confusion so I stopped all exploration of my ancestry. It wasn't until I was taking part in a training session on Indigenous cultures at my former workplace that my curiosity and interest in further exploring my Indigenous ancestry began. We were asked to select a stone from a bag and each stone had one of the seven grandfather teachings printed on it. These seven teachings include humility, honesty, respect, bravery, wisdom, truth, and love. The trainer informed us that whatever stone we randomly selected would be the teaching that we needed in that moment. The stone I selected had 'respect' printed on it. At first, it didn't resonate with me. At the end of the training however, I knew why I had selected that particular stone. I realized that by further distancing myself from my Indigenous ancestry, I was disrespecting my ancestors who had already been erased and ignored by others. I didn't want to participate in their colonization and erasure and so I decided that I needed to somehow start this journey.

Beginning my masters' degree at Ryerson University turned out to be an opportunity to restart my journey towards Indigenous identity. This is quite ironic given that the university's namesake, Egerton Ryerson, composed a letter in 1847, the recommendations of which were implicated in developing a model for future residential schools (Ryerson, 1847). The fact that I was embracing my Indigeneity in an institution whose namesake directly caused the systematic evisceration of thousands of others' identities, histories and families felt as though I was taking back some stolen power. Little did I know at the time that this was my first act of resistance. After much reflection and many conversations, I decided that I had a right to engage in the process of Indigenous identity exploration. This work is important to me as I do not wish to participate in or further the cultural erasure of my ancestors. My hope is that by exploring my 
history, I will give my relations the respect and space that has been stolen from them. Others have erased them, and I wish to bring them back into the light.

This research project is a process and not a result for me. It is a starting point for me to ask: Who am I? Who are my family? How has colonization erased particular people and the teachings of my family? And how do we move forward? I envision this project, literally, like a pathway as the title suggests - leading, each week, to greater understanding and a greater sense of self as an Indigenous woman. I have no idea where this path might lead but I'm willing to trust that it will take me where I need to go. I must move forward with delicacy and mindfulness that Indigenous Peoples have a long and painful history with Western research. In the second edition of her book entitled, Decolonizing Methodologies: Research and Indigenous Peoples, Linda Tuhiwai Smith (2012), discusses how “the term 'research' is inextricably linked to European imperialism and colonialism" (p. 1). Research has been used in the past and continues presently, to cause further harm and oppression to Indigenous Peoples. Because of this, the federal government Panel on Research Ethics revised the 2010 chapter to their guidelines of ethics to follow when conducting research with Indigenous peoples, - the Tri-Council Policy Statement. Chapter 9 of this statement specifically discusses research on Indigenous Peoples, whom the Statement refers to as 'Aboriginal Peoples'. It states that "research involving Aboriginal peoples in Canada has been defined and carried out primarily by non-Aboriginal researchers. The approaches used have not generally reflected Aboriginal worldviews, and the research has not necessarily benefited Aboriginal Peoples or communities" (Canadian Institutes of Health Research, 2014). This problematic history of unethical research has created a movement of resistance within Indigenous research communities. Marlene Brant Castellano (2004), talks about her experience at a gathering for Indigenous Peoples who had been engaged 
in the field of research on Indigenous Peoples to discuss their upcoming research agenda. It was met by harsh criticism with members stating "we've been researched to death!” An Elder who was present responded with "If we have been researched to death, maybe it's time we started researching ourselves back to life" (Castellano, 2004, p. 98). This is precisely my intention.

Who I am has been hidden from me nearly my entire life up until this point. Colonization has worked very successfully in my family given that my dad and I had no idea about our ancestry. Well, not 'no idea', but we'll get into that a bit later. It is my intention to reconnect to my Indigenous roots and to do so in the best way I know how with the resources currently available to me. Through my use of Indigenous methodology, though I am still uncertain of my place in Indigenous community, I am already partially claiming my Indigenous identity . This research is my act of resistance to Western ways of creating and valuing knowledge and in the process, I hope to continue to decolonize my mind and my heart.

Before I begin I would like to acknowledge two things. The first is that Indigenous people do not belong to one culture. There are many cultures within Indigenous communities and so I do not speak for them all. For the purposes of this MRP, I will be discussing my ancestry as it relates to Canadian First Nations and Métis Nations. At this point in my journey of learning more about my identity as an Indigenous person, I often get stuck between identifying as a mixed-race First Nations person or as Métis. Identity is not something that is easily categorized and I hope the path that I'm travelling will provide me with more clarity in time. I also want to acknowledge that, in Canada, the Inuit are another population of recognized Indigenous Peoples but I will not be exploring their process of identity only because I am not of Inuit heritage. In the future, I hope to learn more about the Inuit. The second thing that I wish to highlight is the use of language throughout this MRP. Personally, I choose to use the term 'Indigenous Peoples' as it 
represents those who are the original inhabitants of a land. The term 'Aboriginal' has ties to colonization (Alfred, 2009; Lawrence, 2004; Restoule, 2000; Yellowbird, 1999) and so I'm less comfortable using this word. Use of language is an often debated topic and everyone has their own reasons for their choice and so, when directly quoting from other sources, I will use the language that is within their materials.

Thank you for coming along this journey with me. 


\section{Chapter 2: Literature Review}

There are many different approaches to interpreting a person's identity or belonging within a certain cultural group. Although the literature covers a wide variety of such approaches, this review will focus on the concept of Indigenous identity or Indigeneity in a Canadian context examining First Nations and Métis Nations. Inuit identity will not be explored only because, as previously mentioned, this is not where my ancestry lies.

There are four major themes that emerge repeatedly throughout the reviewed literature.

These themes are: identity determined by the colonizer, shared Indigenous definitions of identity, Métis-specific identity, and the impacts of colonization on identity. Through the examination of this literature, I will provide some social, political, and historical context of the Canadian Indigenous experience, while I explore my own identity as an adult woman who has recently found out about my Indigenous heritage. I hope to better understand the politics of identity creation for the Indigenous community and how my own family fits into this narrative after the erasure of our Indigenous identity due to colonial violence.

When referring to the Europeans who arrived in Canada and began the process of colonization, many people in the literature use the term 'settlers' (Alfred \& Corntassel, 2005; Lawrence, 2003). Personally, it is not a preferred term as, I believe, it implies the Indigenous land and people who existed before the Europeans arrived were unsettled. However, this is the word that is mentioned in much of the literature and for the sake of concision, it will continue in the literature review. I think this speaks to the earlier point that highlights how Indigenous Peoples are not a one-size-fits-all group. There is much diversity including, such as in this example, choice of language. My choice of terminology that I feel is much more reflective of the Europeans' is 'colonizers'. Even this term can sometimes fall short in capturing the violence and 
death that befell the Indigenous Peoples upon the Europeans arrival. Also, the use of the words Indigenous, Native, Aboriginal, and Indian are used throughout the paper to correspond to the differing language found in the literature. The word Métis is used when speaking specifically about this population of peoples.

\section{Colonial/White Identification Systems for Indigenous Peoples}

A very important first step in reviewing literature on Indigenous identity is to go back and examine the significance of history's colonialist involvement with Indigenous Peoples of Canada. It is a result of centuries of colonization that Indigenous identity is a much-debated subject. In order to be federally recognized as an Indian in Canada, one must fall within certain categories of identification as decided upon by government/colonizing standards. These criteria had a hidden agenda of assimilation and it was understood that the more 'civilized' an Indigenous person became they would lose their status and become a part of Canadian society. (Restoule, 2000). Ultimately, with the arrival of the Europeans, Indigenous identity equalled the loss of basic rights.

Since their arrival to what is now known as Canada, Europeans have been in a power struggle over land and resources with Indigenous Peoples. Through several strategic and deceptive policies, European colonizers devised ways to systematically erase the rights of Native Peoples to their land in addition to their identity (Alfred, 2009; Lawrence, 2003; MacDougall, 2012; Restoule, 2000; Smith, 1991). These policies were presented in such a way to Indigenous Peoples making them appear initially positive and progressive but the Europeans had an agenda towards assimilation that would later be devastating to Indigenous populations. The result of these policies was that Indigenous Peoples began to lose their land. 
Lawrence and Dua (2005) point out that "Indigenous stories of the land are both spiritual and political, and encompass tremendous longevity" (p.242). Land, for Indigenous Peoples, is connected to history, teachings, identity, and well-being. Each original homeland of differing Indigenous nations has unique lands (mountains, bodies of water, animals, etc.) that each tell a unique story for the guidance of living a good life. To disconnect people from their land is to break a powerful and living relationship. Oftentimes, the land was taken away from Indigenous Peoples in violent ways. Lawrence (2003) states that "deliberate introduction of devastating diseases and the use of alcohol among the Indigenous nations of what is now southern Ontario and Quebec led to the widespread decimation of population among the nations in those regions" (p. 7). With each step furthering the colonizers' power over Indigenous Peoples, there were laws created that slowly and deliberately took away Indigenous Peoples' rights and alienated them from themselves and their communities.

The Indian Act is the primary document which governs how Canada controls all status First Nations in relation to land, in addition to registration/identification. The Indian Act dictates how reserve lands are to be run as well as identifying what criteria need to be met in order to be considered an Indian by law. The Indian Act remains controversial to this day for a number of reasons, one of which is how it groups all Indigenous People into one category, ignoring the variety of traditions practised between the First Nations, the Métis, and the Inuit. It only took 100 years for the genocidal intentions of the Royal Proclamation of 1763 to become a reality Indigenous lives had been disappeared, and much land had been 'ceded' to the British. 


\section{Shared Indigenous Definitions of Belonging/Identity}

Despite the rigid definitions placed on Indigenous Peoples from the federal government, these definitions do not align with a general understanding of membership and belonging that Indigenous communities generally share.

Importance of relations. While Indigenous nations are each unique, with distinct cultures, traditions, and languages, one trait that all groups seem to share is the primary importance of relationships (Alfred, 2009; Berry, 1999; Thomas, 2005; Wilson, 2008). It is through the relationships between and among nation members that much history and knowledge is passed on through generations. The tradition of storytelling is of particular importance and necessity among Indigenous Peoples, fostering proximity and engagement, two factors crucial to preserving and keeping alive their traditions (Thomas, 2005; Wilson, 2008). Indigenous Peoples are communal rather than individualistic (Alfred, 2009; Alfred \& Corntassel, 2005; Little Bear, 2000, Wilson, 2008); therefore, relationships are integral to the functioning of the group. Berry (1999), talks about identity implying a sense of attachment (to a group) and how one generates a self-concept from membership to a specific group. It is understandable, given Indigenous Peoples experiences of colonization over hundreds of years that relationships, specifically trusting relationships, are of primary importance for safety and survival. With relationality comes security. What's important to remember is that Indigenous Peoples consider themselves to be in relationship with all living things on earth, not just people. In her doctoral dissertation, Cora Weber-Pillwax (2003), states that "all forms of living things are to be respected as being related and interconnected" (p.49).

Relationship to land. Not only are relationships among people in the Indigenous community important, but so too is relationship to land and environment (Alfred \& Corntassel, 
2005; Lawrence, 2012; Wilson, 2008). Land is a great source of spirituality, and Indigenous Peoples look to the land to provide teachings and guidance. Those who are disconnected from their lands are losing out on the important teachings and connections necessary for Indigenous survival. It is not a one-sided relationship either as there is an agreement of give and take between the person and their environment so as to ensure the continued support by the land. Sadly, loss of land, either through theft or displacement, is common among many Indigenous communities'. This loss has a negative consequence to their sense of identity and belonging as it breaks the relationship between person and land. The connection to land is said to help Indigenous Peoples to survive as a distinct people. Wilson (2008) shares that for him, "we as Indigenous people have a literally 'grounded' sense of identity. The ground and environment from which we came is what makes us" (p. 88). More specifically, Indigenous Peoples recognize that different territories are made up of different plants, animals, and landscapes and therefore believe that each community's land and territory is specific to their teachings and identity.

Tribal affiliation. When European colonists arrived in Canada, they used a variety of divisionary policies based on race that set them apart from the Indigenous Peoples. Though this was an accepted method of classification for Europeans, this is not the way that Indigenous Peoples categorized themselves. In much of the literature, it is clear that Indigenous Peoples do not identify themselves in term of race and instead look to tribal affiliation as a system of classification (Alfred, 2009; Lawrence, 2003; MacDougall, 2012; Restoule, 2000; Yellow Bird, 1999). In Taiaiake Alfred's 2009 study of First Nations perspectives on identity there were common themes that participants agreed on when it comes to their Indigeneity: place, culture, clan, lineage, way of life, oral history. The colour of one's skin was not important. 


\section{Métis Identification and Belonging}

The Métis share many similar worldviews of First Nations/Indigenous Peoples discussed above such as the importance of land, relations, and nationhood. To be a Métis person can also sometimes result in feeling torn between two or more identities.

Stuck between two worlds. Simply put, to be a Métis person is to be a "descendent of people born of relations between Indian women and European men. The initial offspring of these unions were of mixed ancestry. The genesis of a new Aboriginal people called the Métis resulted from the subsequent intermarriage of these mixed ancestry individuals." ( Métis Nation of Ontario, n. d.). Métis is a term unique to Canada. Métis themselves are recognized as neither exclusively White nor First Nations. Having the blood of and therefore connection to both groups, Métis Peoples have found themselves stuck between two worlds when it comes to identity creation/group affiliation (Lawrence, 2012; MacDougall, 2012; Naumann, 2008; Richardson, 2004; Turner, 2010). Métis researcher, Cathy Richardson (2004) discusses how Métis people find themselves navigating between three distinct spaces: the first being the dominant or White space, the second being the First Nations space, and the third being the Métis space. She explains how many Métis peoples do often dip into the second space, but that it does not provide teachings or support in how to navigate a mixed heritage. Richardson (2004) believes that "a third space offers a place where hybridity, or being mixed race, can be experienced holistically and celebrated as central to Métis culture” (p.66). Métis people are their own nation similar to Cree, Chippewa or Algonquin in that they have their own traditions, teachings, creation stories, and traditional dress. 


\section{Colonization's Impact on Indigenous Identity}

To get a better understanding as to why there is no unanimous or agreed-upon definition of Indigenous identity, it is important to review literature that gives historical context to the issue. In present-day discussions about colonization, it can mistakenly be believed that colonization is something that happened centuries ago through warfare and genocide. What fails to be recognized is that colonial actions, policies and attitudes are still alive and well in present day Canada further complicating the already contentious issue of Indigenous identity. Alfred and Corntassel (2005) contextualize this point saying "not all Indigenous peoples were 'conquered' militarily by the colonial powers that now dominate them. Treaty-making, rather than outright military conquest, took place in North America on a wide scale [...]” (p.607). Though treaties were originally created as agreements between the Crown and Indigenous Peoples to peacefully co-exist together, these agreements have not been honoured by the Crown leaving Indigenous Peoples to suffer the consequences of poverty, stolen land, and near-constant erasure. Indigenous Peoples need not have gone through military warfare to be considered conquered or colonized. Modern-day warfare takes the form of treaties and policies created by settlers and colonizers. To believe that colonization is over furthers the disappearance of Indigenous lives.

In-fighting. Through its recognition and classification of status and non-status Indians, the Indian Act has created a divide not only among First Nations people but also with the Métis. The groups have fought internally amongst themselves, and have also battled with each other (Alfred \& Corntassel, 2005). It is widely felt that the creation of in-fighting amongst Indigenous groups is a colonist's tool to prevent group solidarity and strength needed to challenge the oppression they face (Alfred, 2009; Alfred \& Corntassel, 2005; Allen, 1999; Berry 1999; Lawrence, 2012; Richardson, 2004). If First Nations and/or Métis groups are battling with each 
other, this works in favour of the colonizer as the groups are spending their time and energy fighting with each other as opposed to turning their attention to the bigger colonial oppressor. Creating the conditions for internal strife makes it much easier for the powerful to continue their reign. Non-Indigenous interpretation of the Indian Act seems less about Indigeneity and more about the competition for limited resources, wherein land transfers and other resources were accorded based on arbitrary racist categorization of one's identity as Indigenous; this practice of tying resources to identity was sometimes reproduced within Indigenous communities, thus fostering in-fighting for the scarce resources accorded to any Indigenous peoples by the colonizers (Allen, 1999). Indigenous Peoples are not afforded the same rights and opportunities as others and so they must compete with each other for survival.

Internally, Métis peoples battle among themselves as to who has rightful claim to call themselves Métis. Some believe that true Métis people, and then by implication the only ones who should use the title, are descended from the Red River region in Manitoba (Sawchuck, 2016). Taking into account the systems of categorization and identification imposed by the Canadian government as well the ones generated and applied by Indigenous Peoples themselves, it is evident that there is ample room for infighting and disagreement, especially where terms and labels have legal and cultural consequences. My sense is that those who are non-status Indians (not recognized by government legislation) and those who identify as Métis are in a constant position of jockeying for a place to belong. It leaves one to wonder who is 'allowed' to label themselves and based on what criteria.

Indigenous ancestry hidden. For much of Métis history, it became dangerous for mixedblood people to identify as having Indigenous background as it made them targets for violence. This threat of harm furthered the colonizers' agenda of erasing Indigenous Peoples and their 
traditions. Many Métis people have experienced their Indigenous ancestry being hidden from them (Berry, 1999; Lawrence, 2012; Naumann, 2008; Restoule, 2000; Turner, 2010). Often, the result is that mixed-blood people discover their Indigenous heritage years, if not generations later and they find themselves confused about their identity.

As a means of protecting their children from the harm of violence that came from identifying as Indigenous, Indigenous parents including Métis parents, would sometimes eliminate traditional practices such as language and song from their children's lives (Lawrence, 2012). Though this strategy could be viewed as useful to keeping their children away from colonizer violence, it still had the colonizing results of erasing the traditional teachings and knowledge of their nation. Bonita Lawrence (2012) uses the Algonquins' of the Ottawa Valley as an example of this inadvertent erasure of culture. This is my nation. This Algonquin nation has been almost entirely decimated by two separate colonial shows of force over a 400-year period. Their land has been almost completely taken from them and put into the hands of colonizers. Lawrence (2012) shares that:

In a context of settler violence, silence was forced upon Algonquins. Survival was precarious and to openly express any aspect of an Algonquin identity - through language, song, or story - was enough to provoke further violence from settlers. To pass this knowledge along to one's children was thus to potentially endanger them. (p. 116) It was the act of even identifying as an Indigenous person, of having pride in who you were that put your life at risk. The original Indian Act basically made it illegal to be Indigenous, except in extraordinarily restrictive terms. Indigenous erasure wasn't just a horrible and racist societal norm, it was codified in a legally enforceable document. Though not as overt a threat in today's 
society, albeit this depends on where you are living, identifying as an Indigenous person is still fraught with tension and violence.

Mourning. A natural result of the division, categorization, oppression, and colonization of Indigenous Peoples is a deep sense of grief. People are feeling disconnected from their families and lands and the result is a collective mourning (Alfred, 2009; Alfred \& Corntassel, 2005; Smith, 1991, Turner 2010). As the result of colonization and the displacement of thousands of Indigenous bodies over hundreds of years, people like me are learning of their Indigenous heritage later in their lives; they are so disconnected from their families and original territory that they're not sure where to begin or who to consult. Smith (1999) shares that "Imperialism and colonization brought complete disorder to colonized peoples, disconnecting them from their histories, their landscapes, their languages, their social relations, and their own ways of thinking, feeling, and interacting with the world" (p. 28). The only thing left to do at this point, is provide a space for grieving one's profound loss.

\section{Analysis of Literature}

A traditional literature review in a Westernized research project would have me analyze and critique other writers' works. While simultaneously in a practice of researching within a Western institution and reconnecting with my own Indigenous ancestry, I will be attempting to use the Indigenous practice of relationality within my discussion and therefore doing my best to eliminate critique and rather use exploration. As Shawn Wilson (2008) points out "critiquing others' does not fit within the Indigenous framework. It doesn't follow the axiology of relational accountability and criticizing would imply I know more about someone else's life than they do" (p. 43). I am grateful for the writers who have come before me as they are putting into context what my family has experienced for generations. 
Existing knowledge of the subject. Almost the entire collection of resources that was reviewed was performed by people in academic positions, namely, professors. The knowledge they have to share is important as most of them have both lived experience of being involved in Indigenous community as well as the academic teachings and understanding to unpack colonialism and its destructive effects. Ironically, even with so much academic literature, it was very challenging to find empirical research on Indigenous identity formation. Empirical research is highly valued in Western education as it claims to be impartial and objective. Coming full circle, it is for this exact reason then that much of true Indigenous research is not categorized as empirical, since academic "distance" is not seen as a hallmark of Indigenous research. In fact, Indigenous researchers (Alfred, 2009; Berry, 1999; Thomas, 2005; Wilson, 2008). believe they must be involved in the project for relationality purposes - something critical to Indigenous culture. This centring of empirical knowledge perpetuates the discourse that Westernized/colonized knowledge is the 'one true' knowledge. Indigenous knowledge isn't credited with holding valuable teachings and information for all. Smith (2012) says that the struggle for the validity of Indigenous knowledges may no longer be over the recognition that Indigenous Peoples have ways of viewing the world which are unique, but over proving the authenticity of, and control over, our own forms of knowledge" ( $p$. 108).

Wilson (2008) talks about how, because of this focus on Western ways of knowing, "unfortunately, Indigenous researchers have often had to explain how their perspective is different from that of dominant system scholars" (p.55). You can see this from my own justifications and explanations of my choices for this very research paper echo Wilson's point. In not choosing a Western theoretical framework nor a Western methodology from which to centre 
my findings, my research paper could easily be deemed by Western institutions as unreliable, without rigor, and without significance. I, however, would beg to differ.

Knowledge that is invisible. What I have found in reviewing the literature of Indigenous scholars, or rather have not found, are people like myself and my dad, those who have Indigenous ancestry but did not find out until they were an adult. It would have been interesting to read how others have navigated this path and what challenges and victories they accomplished along the way - mentors of sorts, normalizing the confusion, isolation, and pain of the process.

Knowledge or teaching about the practicality of reconnecting to the communities of our original nations is also missing among the literature. There is much theoretical and historical understandings of why a community can become divided, but little in the way of guidance as to practical steps one could take to reconnect. This is something that I really struggle with in this journey and hope that through connections to different Indigenous communities in my future, I'll learn through the practice and teachings of others.

Accessibility of knowledge. The literature reviewed is academic in nature, which makes the information inaccessible in a number of ways. First, this information is written and published within scholarly journals which typically means that you have to have access to an academic database to read them. This immediately eliminates a large majority of people, Indigenous or not, from being able to read the material. Secondly, even if interested readers were able to obtain a copy of the journal articles, they likely won't find it an easy or understandable read due to the high jargon content. The choice of language used lends itself to an academic ear and unless a person is familiar with this language, it may turn them off the reading due to inaccessibility. Through reviewing the literature of Indigenous identity politics and formation it is clear that there is much division and difference of opinion. There are multiple groups, each inspired by 
different motivations, and each with very different levels of power to operationalize identity. What is clear, however, is that those people with Indigenous ancestry have been silenced and ignored by the government when establishing criteria for belonging. Questions remain about why it is government controlling for Indigenous identity and why this can't be placed back into the hands of the differing communities or nations. It is my hope in my research to begin exploring the people left 'in between' the two groups of colonizer and colonized - who identify as having ancestry to both and how they navigate their past, mourn for their loss, and rebuild and reintroduce themselves to those in their communities. 


\section{Chapter 3: On Methodology and Theory}

For the purposes of this MRP, I will be using Indigenous-based research methodology. Coming to a decision about this methodology was a difficult and confusing one. I'd like to walk you through my process in the spirit of the transparency of my (continued) learning. Being in a Westernized school system for my whole life, I have been taught Western ways of learning and researching. Commonly, this involves the researcher being as objective and removed from the research process as possible as it is perceived this will give more rigorous results. Little Bear (2000) discusses how this "manifests itself in the thinking processes of Western Europeans in concepts such as one true god, one true answer, and one right way" (p. 82). If it isn't done in the Western way, then it will be viewed as flawed and unreliable. Separate, detached, and objective knowledge was what was valued and taught to me in my academic career and so naturally, when I began to think about what I wanted to research for my MRP, I was incorporating these values into my research process. Initially, I wanted to interview Indigenous female survivors of sexual violence to better understand what their views of justice looked like and compare this to what they felt they had received. I consulted with an Indigenous professor on campus, Lynn Lavallee, about my idea and in a very brief amount of time, she helped me to realize I first needed to move backwards and to be clear on my own Indigenous identity prior to engaging with the community in such an intimate and personal way. I very much valued her input and quickly changed the direction of my research - towards myself.

This was a difficult decision to grapple with as it flew in the face of detached and objective Western research methodologies - I would be researching me. I found another Western methodology - autoethnography, - which allowed my own voice into the narrative even as the researcher. Autoethnography has multiple meanings but it is largely based on people researching 
themselves in relation to others (Reed-Danahay, 1997). At the time, this seemed the best fit and so I went about researching autoethnographic methodologies. As I came to centre in on the topic I wished to explore - Indigenous identity formation - and began the process of reviewing literature from Indigenous writers and researchers, I quickly realized that a Western methodology of autoethnography was not appropriate and, in fact, reinforced harmful colonial practices. Western research methodologies and theories are often upheld as the dominant or better way of conducting research which often came at the expense of the Indigenous Peoples they were studying. While finding Indigenous Peoples good enough to use for study, Western researchers would then invalidate Indigenous ways of knowing and understanding the world. It was my intention to amplify and immerse myself in Indigenous knowledge for my MRP and not to further its erasure. Absolon and Willett (2004) state that "Aboriginal and non-Aboriginal researchers who tackle any facet of Indigenous study accordingly must have a critical analysis of colonialism and of research methodology as an instrument of colonization" (p. 9). It seemed colonial methodologies and practices were everywhere I turned.

I also ran into a similar challenge when selecting a theoretical framework for my MRP. In the sense that methodology is a 'lens' through which one views a topic, a theory serves to provide a generalization about what is being studied. It's a way of explaining how something occurs. This is a significant decision to make in the research process as it will affect the way in which you interpret your findings.

A tempting first place to turn to was Postcolonial and Critical Race theories. My assumption prior to doing any reading was that each of these theories would likely address the effects of colonization on Indigenous Peoples and critically examine the challenges of Indigenous identity through this necessary lens. After much review of the literature, it just felt as 
though something was lacking in these theories' ability to capture the devastation of colonization and imperialism on Indigenous Peoples. Lawrence and Dua (2005) argue that "anti-racism theory participates in colonial agendas in two ways; first by ignoring the on-going colonization of Aboriginal peoples in the Americas, and second by failing to integrate an understanding of Canada as a colonialist state into anti-racist frameworks" (p.238). What they also failed to address is the centralization of nationhood rather than race amongst Indigenous Peoples. Indigenous Peoples identify themselves based on the nation they come from, for example, Algonquin, Chippewa, and Mohawk. Yellow Bird (1999) shares that

Indigenous Peoples in the U.S. and Canada have not regarded themselves as one monolithic racial society $[\ldots]$ they have also often viewed one another as diverse peoples, distinguishable according to language, behaviour, dress, geography, foods, technologies, creation stories, and numerous other characteristics (p.2).

Race is not something that is centred in Indigenous life and so I could see these two theories already not being truly representative of Indigenous realities.

The next step was to keep reading and looking to Indigenous scholarship to find some guidance. Porsanger (2004), quotes Elisabeth Cook-Lynn, a Crow Creek Sioux woman who argues that "while it is important that scholars become theoretically informed, Indians should define their own perspectives on Indian history and culture instead of relying solely on the thoughts and dictates of anthropology and history theorists" (p. 110). This speaks to the earlier point that was raised around Indigenous Peoples history with research. Much of the historical research on Indigenous Peoples was done by colonizers through a colonizing lens. They recorded events and behaviours of Indigenous Peoples describing details of rituals and ceremonies but did so without any knowledge of the significance or cultural relevancy to the Indigenous Peoples 
who were performing them. What I believe Cook-Lynn is pointing out, is that if Indigenous Peoples use the theories that were constructed by a colonizing eye, then they're going to miss critical pieces of their history and culture and further contribute to their own colonization.

What was made clear in numerous writings by Indigenous authors and researchers was the task of decolonizing oneself in both the mind and in practice in order to ethically engage in Indigenous research which is based on Indigenous ways of knowing. Again, having been educated solely in Western institutions my whole life where colonial practice is deeply embedded, decolonizing myself would (and will) prove to be a monumental (and lifelong) task. In seeking out my research methodology and theoretical framework, I became convinced that decolonization must be central to exploring the history of Indigenous erasure and Indigenous ways of knowing must be used when exploring Indigenous identity. The 'one true' Western way would not be authentic or a true representation of Indigenous Peoples' stories - a new way must be explored.

Simultaneous to finding the answers to my research method and theory questions I also struggled with other questions, namely: Do I have a right to do Indigenous-based research being so 'new' in the community with very little knowledge of cultural values and practices? The last thing I wanted to do was culturally appropriate Indigenous knowledge for the sake of my research. More work and consultation with the Indigenous community was needed.

I went to another Indigenous professor of mine, Cyndy Baskin, to speak to her about my issues with identity and my research project. She was immediately accepting of me as Indigenous and quickly helped to connect me to the Ryerson Aboriginal Student Services (RASS) office on campus. I met with an academic advisor there who also made me feel instantly welcomed and supported. She connected me with the campus Elder, Joanne Dallaire, and my 
journey to Indigenous identity cracked wide open. She spoke in terms of the four directions and the battle between my head, heart, body, and spirit being pulled in so many different ways in relation to my research. My mind was telling me to use Western methods, my heart was telling me to use Indigenous methods, my body was tired from bouncing between the two thoughts, and, in the end, my spirit guided me to the place where I could find the answers. I no longer questioned my right and responsibility to use Indigenous methodology for my research. Now, I could immerse myself within it.

\section{Indigenous Ways of Knowing}

Smith (2012) also uses the four directions in reference to the processes of Indigenousbased research which she states include "decolonization, healing, transformation, and mobilization" (p.120). She makes clear the point that these are processes in research and not goals in and of themselves. This was an important reminder to me that I don't have to have all of the answers before I even begin. Though this MRP is being written in order to fulfill an academic requirement of my masters program, Indigenous research reaches far beyond this one institutional realm. Kathy Absolon (2011) shares that "our journeys are not just about academic knowledge; they are about our journeys home, to our communities, to our ancestors, to our territories, to other territories and to our families" (p. 93). Indigenous research joins us with our communities, in fact, this is a must according to Wilson (2008) who believes that relational accountability and engagement are necessary in Indigenous research if it is to be ethical, authentic, and culturally responsible.

Absolon (2011) believes that "just by being Cree, Anishnaabe, Mohawk, Sto:lo or whatever nation - to some degree we are Indigenizing our methodologies. Our very presence in our journey enacts an Indigenous methodology" (p. 118). How comforting to know that my very 
existence offers me knowledge and gifts that can help me in my research journey. Absolon

(2011) also talks about her own research journey as an Indigenous woman saying

being an Indigenous person in a search for knowledge situates me in a place that non-

Indigenous people can never occupy. We have inner cultural knowledge and common experiences of colonization and its subsequent impacts on our families, communities and other relations in Creation (p. 63).

This also raises an important and overarching symbol within many Indigenous cultures:

the medicine wheel. The medicine wheel is an ancient symbol used by almost all North and South American Indigenous Peoples. It is also sometimes referred to as the four directions, the four grandfathers, or the four winds. It is a circle made up of four equal quadrants each representing different aspects of ourselves and the world in which we live. It teaches us that all races (red, white, yellow, black) are part of the same family, that all elements (wind, water, air, fire) are all a part of the world, and that all aspects of a person (physical, mental, spiritual, emotional) come together to create a whole and healthy person. Little Bear (2000) sums up the medicine wheel nicely when he states that "all things are animate, imbued with spirit, and in constant motion. In this realm of energy and spirit, interrelationships between all entities are of paramount importance" (p.78). This also reinforces the importance of relationships and community earlier highlighted by Wilson (2008). For the purpose of this MRP, it is the teachings of the medicine wheel that will be used as methodology. These teachings will be applied when later discussing and analyzing the stories that are shared between me and my dad. The medicine wheel is a symbol that Indigenous Peoples use to guide their lives and walk in a good way so it only seemed appropriate to use this to guide my Indigenous research and ways of knowing. 
By centering the medicine wheel in my research, I act to further decolonize myself as well as Western academia. The process of decolonization allows for Indigenous Peoples to take back control of their lives, to set their own goals and agendas, and to pursue them in a way that best serves their needs. Smith (1999) states that

decolonization does not mean and has not meant a total rejection of all theory or research of Western knowledge. Rather, it is about centering our concerns and worldviews and then coming to know and understand theory and research from our own perspectives and for our own purposes. (p. 39)

\section{Method}

The next step in my journey was to select my research method, or, what tool was I going to use to collect the information I wanted to examine. In keeping with my Indigenous methodology, I wanted to pick an Indigenous method and so I selected storytelling. Thomas (2005) shares that "a storytelling methodology honours [...] tradition and the Ancestors. I feel that storytelling enables us to keep the teachings of our Ancestors, culture, and tradition alive throughout the entire research process" (p. 242).

My research, more specifically, involved me and my father meeting to share stories with one another about what it was like to learn of our Indigenous ancestry so late in life, what memories we have of Indigenous knowledge or teachings from our past, and what plans we have for our future with respect to involving ourselves in Indigenous community.

In her article entitled, 'Storytelling Circles: Reflections of Aboriginal Protocols in Research', Cyndy Baskin (2005), shares that:

Storytelling is a valid form of Aboriginal knowledge as it includes responsibility on the part of the listener/researcher, incorporates both interpretation and analysis, has room for 
many explanations for the phenomena being researched, is a creative search for solutions, and is a political act of liberation and self-determination (p. 178).

This was a more appropriate substitution for my previous interest of using the Western practice of autoethnography so that I could incorporate myself into my research. By engaging in storytelling, I am not only listening to my dad's experience of what his process has been in forming an Indigenous identity, but I also have the opportunity to talk about my own experience. By listening to each other's stories, we can strengthen our relationship, and learn from each other in the process.

The challenge with the Indigenous storytelling method is that people's views can change with time and the stories that are captured in this research project may not be the same years down the road when others may be reading it. Wilson (2008) addresses this issue in a letter to his sons saying that "all stories reflect the storyteller and where they are in their lives. A problem with writing down stories is that it makes it very difficult to change them as we gain new learning and insights" (p. 22). I can certainly appreciate the truth of this point since my learning and knowledge from the beginning of this project up to this very point has grown and changed enormously. This goes back to the previously made point about this journey being a process, and not a goal. Much like identity, knowledge is not fixed but fluid - always changing and always molding with time.

During our storytelling meetings, the conversations between me and my dad were documented via audio-recording and then transcribed and coded using the medicine wheel teachings as a guide. My process for choosing what points of discussion to share for the purposes of this MRP were to code the variety of themes that arose during our conversations and then explore and highlight those themes that were most frequently repeated in our stories. There is no 
outline in Indigenous research for how to select for and extract from one's data set. It's really more a matter of following Indigenous teaching principles. Kathy Absolon states that, "what we see revealed through Indigenous research is the re-searcher, the self. Within the self exists millennia of Indigenous ancestral knowledge, teachings, and Spirit” (p. 67). And so, I looked to myself, my teachings, and my spirits to properly guide me in sharing our stories in a good way. Prior to our storytelling meetings, my proposed idea for this MRP was submitted to the Research and Ethics Board (REB) at the university for approval. There were many proposed amendments from the REB that didn't align with Indigenous research methodologies but instead were more suitable for Western methodologies. The biggest suggestion was to not have my dad's identity revealed as this is a major breach of confidentiality - a typically non-negotiable issue of privacy for research participants. However, this project was speaking to the effects of generations of Indigenous erasure due to colonization and I felt that eliminating my dad's identity from the project was furthering this erasure we were fighting so hard against. In the end, his identity was allowed to be shared, and with his consent (see Appendix A), we began our journey.

As is documented in his consent form, he was a part of the process from beginning to end. At any point in our research project, he was able to review the information and request either additions or deletions to his contributions, which was respected and honoured. To ensure relational accountability, all those involved in this research project had the opportunity to make suggestions based on their best interests and those of the community. An Elder also was consulted throughout this research project to ensure cultural appropriateness and accuracy.

In an essay on Indigenous methodology, Jelena Porsanger (2004) echoes the above decisions made when pursuing Indigenous research: 
Some of the most important issues for indigenous methodologies may be itemized as follows: defining the indigenous agenda for research projects; looking at researching and theory from an indigenous perspective; including or consulting indigenous peoples, not as objects but rather as participants, to predict possible negative outcomes, to share and protect knowledge, to use appropriate language and form in order to communicate research results back to the people, etc. Reporting back is one of the most important imperatives of indigenous research. All these issues are based on the principles of respect, reciprocity and feedback (p. 113).

To sum up my chapter on Indigenous methodology in research, I want to share a vision I had when grappling with some of the issues that were coming up for me in this project. I struggled to figure out a way to write my MRP in a way that was true to my Indigeneity while simultaneously existing in a Westernized institution. The institution was dictating exactly what I needed to do right down to providing a template for how to structure my words and this was in direct contrast to Indigenous ways of being and knowing. I went searching for answers to help me navigate between the two worlds. In a conversation with an Elder about my struggle, I found the answer that I was seeking. She told me that, "our voices were taken from us, particularly in schools, and we're just trying to stay alive. Fundamentally, Indigenous people had to assimilate that's colonization. Using colonized constructs to talk about colonized people is not going to work" (J. Dallaire, personal communication, May 15, 2017).

During this same conversation with the Elder, I had this vision that helped to provide me with some peace. I had a bird's eye view of an eagle flying above a forest observing what was below. On the ground was a thick and beautiful forest, trees bursting with dark green leaves. Very clearly through this forest, however, were two very clear-cut paths, each running parallel to one another separated by the thick forest. This vision is how I view my journey in writing this 
paper as well as your journey as a reader and how some things I talk about may not always make sense to you. You see, I didn't want to spend my whole paper explaining my every decision, or direction change, or justification for being on an Indigenous pathway rather than a Western one. Very simply put, we are not going to make the same meanings from my story. If I was walking on the Western path described in my vision and looked up to see an eagle flying overhead, maybe I would notice it, maybe not. I would likely think it was beautiful and watch it for a while and then continue down my path. On the other hand, as an Indigenous person on the Indigenous path, if I look up and see an eagle flying above me I see a brother, a sister, a helper. I am in relationship with this eagle. He presents himself here to help and I know that I am protected.

The purpose of me sharing my vision with you and the struggle I've had in my research journey is two-fold. First, I am doing this so that you're aware that my lack of explanation at certain points is intentional - that some things will only hold special meaning for certain readers. Secondly, this is a call to action for you, the reader. The Truth and Reconciliation committee states that it's your responsibility, as a non-Indigenous person, to educate yourself and to not rely solely on Indigenous Peoples to do this for you. So, in sharing my and my family's story, I invite you to take yourself from passive observer to active learner. Welcome to my story. 


\section{Chapter 4: What We Discovered}

There was difficulty in trying to construct this part of my and my dad's story which seems to be an ongoing theme in this journey. I tried to map it out on paper in a hundred different ways. It wasn't making sense. I wanted to convey all the complexities and beauty of the stories being shared in a clear and linear way. I decided to speak it out - aloud. Speak as if I'm explaining it to someone who doesn't know what I'm researching. And so I did. I recorded myself telling this story before I was able to put it on paper. I later realized that this was the tradition: oral storytelling. And it had come so naturally to me. It's a great comfort to know that I practice the traditions in the way in which I live my life, instinctually. And so I hope as you read what is below, you can envision me speaking this to you. Telling the story of my family's rebirth. It's not your typical 'results' section in a research paper. It's part story, part poetry. Turn off your Western-educated brain, decolonize your mind, and let's walk down this path together.

\section{Introductions}

What I feel like I've learned in this process is that my dad and I have both walked down different paths in our lives, at points, of course, intersecting. Certain cycles of isolation and violence were broken, and other cycles of love and belonging have been created. We each have contributed to the breaking and the mending of these cycles over time and I'd like to share some of those stories with you. But my dad had lived this whole life previous to my existence and that's where I'd like to begin. My dad's name is Jim, or Jimmie, or James depending on who you're speaking to. Jim Giroux. He was born in Pembroke, Ontario in 1951. He is the youngest of five siblings. He's also my favourite guy. 
As mentioned previously, I am Shanna Giroux. My first name also mutates depending on who I'm talking with. I was born in Thunder Bay, Ontario in 1982. I am Jim Giroux's only child and we are of Algonquin ancestry.

\section{New Language, New Name}

In our conversations for this research project, my dad spoke a lot about the pain and the struggle of growing up. As a young boy his first struggle began as soon as he began school. He was put into a French Catholic school despite him not knowing the language. At home they spoke only English and so when he asked why he had to be at a French school he was told "you are French and so you go to a French school'. Identity crisis number one at the age of five. Not only was he forced to learn a new language, but he was also given a new name. His name was changed from Jimmie to Jacques as this was the closest French translation. If he didn't write his name as Jacques on any of the papers or tests he submitted to the teachers, they wouldn't grade them and would throw them in the garbage. So he had to change his name. Who he was. Learn this new name. Learn this new language. If you don't change your name and learn this new language then we will fail you and you will not move forward. So he began his life not really sure of who he was. He had an idea of who he was, he thought he knew who he was but other people were telling him "no, that isn't who you are". And these were just the known parts of who he was - his name and his language. There was a whole other unspoken and unknown aspect of his identity he didn't even know he was wrestling with at the time. His Indigeneity. But a part of him said that there's something else. In our conversations he called it a "curiosity". So he grew up in this place of confusion, in this place of isolation, pain, erasure, and struggle - this constant battle of declaring, "This is who I am" and someone telling you, "No it is not". And if you don't 
start saying who you are based on who we believe you should be there will be violent consequences.

\section{Family}

Despite existing in this space of violence, he went on in his life, helping his mom, his grandmother, and his grandfather. He spoke a lot about the caretaking roles that he stepped into as a child and a youth. He would help his mom to write - she didn't have any formal education. She had two weeks of schooling in her whole life and so she didn't learn how to write. She would dictate her letters to him and he would write to her sisters out of town and to her brother who was in the army. He was trusted to bring home his report card and tell his mother what grades he had received as she couldn't read either. All she cared about was that he passed. So he would have to write the letter of response to the school, as though coming from his mom, saying that she had reviewed the report card and then the only thing that she was able to write herself on the page was her name. This is the only thing she learned how to write - her name.

There's a recurring theme here - the importance of one's name. It is through his mother's lineage that we have Indigenous ancestry and so it is interesting that her name is the one and only thing she learned how to put on paper. The reason it's noteworthy is that names were something that were taken from so many of her ancestors before her and it was taken from her son as well.

My dad would also help his maternal grandmother do basic things around the home; he would help to take care of her because his grandfather was always out in the bush. They would sit and talk about the family or what was happening in the town and he would keep her company. He would help his grandfather as well. He would go into the bush, into nature, to help him log with a horse and not much else. My dad describes them as some of the happiest memories he has as a child - listening to his grandfather play the accordion and his great uncle play the fiddle 
while dancing and sharing a glass of brandy. A favorite story of mine that he told me about was when he and his grandfather were at the camp in the bush there was a stream that ran through it and so they would take a big metal pail and fill it with river water and set it over a fire to boil. One day my dad said "Pépère, there's a minnow in the bucket" and his grandfather told him "Don't worry, when it gets warm it will come to the top". And it did, so my dad scooped it out and put it back in the river. No harm done.

He never received these teachings from his grandparents, as part of any formal Indigenous learning, at least they weren't named as such. And here presents this name issue again. Lessons are taught and knowledge is shared but they are never named as Indigenous teachings. My dad says that his grandparents never spoke about their past. It was as though it had been completely erased from their minds. He would get this teaching of taking only what you need from the earth. Take only the water that you need from the river; if there's something in there that you don't need, you take it out and you put it back where it came from. You don't harm what you don't need to harm. Those fundamental teachings were given to him; just not in a way in which was named. At that point in my father's life, nothing yet in his world had an identity as far as Indigeneity was concerned.

\section{Leaving}

As soon as my dad could leave, he left. He left. And there was this expectation that you had one of two options when you left Pembroke. You either went to Sudbury to work in the mines or you went to Kitchener to the Schneider factory. His mother said that she wouldn't allow him to go to the mines because it was too dangerous, and so he pursued the second option to go to Kitchener. That was the direction in which he was going (west), and while on his way to Kitchener he first passed through Port Hope where his brother lived and so my dad decided to 
stay there for a while. My dad stayed with his brother for some time to work, quite often alone, and making a name for himself there. And it was his brother who said to him "Why are you going to Kitchener? You can find work here." And so my dad stopped the cycle there. He stopped that Pembroke cycle - he stayed in Port Hope and he worked.

Just as one cycle was broken, however, an old one reappeared: an issue with his name. In his hunt for a new job, people would see his last name and pass judgement. There was a problem with him being this French guy. It's ironic because he was being judged based on his French bloodline which he really hadn't connected to at all apart from beginning school and being forced to speak the language. I grew up knowing we had French ancestry as my dad knew the language but would rarely speak it. His French tends to come out only when he's really excited or really upset. But this is always how people have identified me as well - French, solely because of my last name. So, back to my dad's story - he gets a job at the Ministry of Transportation and he breaks yet another cycle within the workplace itself. Traditionally, people would be hired based on who they knew or through the masons. My dad got in on his own accord and so people had a problem with him and tensions formed. I think that though his presence led to problems within the institution, he created freedom in himself. He broke this pattern and started something new. And I really feel that this is where my story comes in.

\section{A New Generation}

He had lived many years by then without me, but had since met my mom and they moved around a lot. They moved all over southern Ontario and were very unsettled, staying no longer than a few years in one city. And when they had me I was born in Thunder Bay, Ontario and this is kind of my beginning story. 
I lived most of my life, 32 years, not knowing my Indigenous heritage. However, when I was born I was born with this jet-black hair. My dad and my mom have both made comments about how I looked like a little Indian baby when I was born. And I really think that was a physical manifestation, a physical indication that there was going to be a spiritual regeneration with my birth. A reawakening.

In an event that is so symbolic of how our journey to identity has gone, after four to five months of life, all my hair, all my black hair fell out while I napped. I slept and my hair fell out. Then it changed. It changed from black into a light brown and it stayed that way for a long time of my life. I find it so symbolic in the sense that there is this part of you that exists, that's deeply embedded, but for a while you're not going to know about it. You're not even going to be able to see it. It's going to go dormant. Like many forms of life go dormant in the winter, it's going to retreat for a while. And it did for 32 years.

What's interesting, though, is it just seemed to go dormant for me, from my perspective. Other people who I'd come across in my life, mostly strangers, would ask me if I was Indigenous. It happened and continues to happen all of the time. And I'd say "no". And some people would actually argue with me and assure me that I was, just based on a quick interaction in a mall or on the street. It was strange but it always made me feel happy to know that this is how I appeared to people. I remember that once I found out that I was, in fact, an Indigenous woman, I remembered back to all these instances where I denied who I was, and I felt devastated that I had negated my identity for so long without being aware of it. So, perhaps it's fair to say that the dormancy was only in my own heart because outsiders seemed to know who I was immediately. 
Back to my dad and a story that he shared with me: That after I was born, he and my mom had a conversation about how I was growing up to know that family was only a mom and a dad (as I am an only child) and they wanted me to know that family was much bigger and included aunts, uncles, cousins, and grandparents. With this in mind, they made the decision to move to London, Ontario, where my mom's family lived, to give me a sense of stability and a sense of home. And they did. They succeeded. They stayed and have remained there for 30-plus years. That was where I grew up with my family, both extended and nuclear, and I grew up a very happy, safe, and loved child.

It was here that we became more knowledgeable on Indigenous issues as my aunt's longtime partner is an Indigenous man. His name is Joe Miskokomon and they live on Chippewa of the Thames First Nation. From the time we arrived from Thunder Bay, their home has always been my favourite place to visit. They have dogs, and cats, and horses so what small child wouldn't love it out there? But it was something else too. I always felt at peace on the rez (as we affectionately refer to it). My uncle was Chief in his community for many years and he is an extremely intelligent and engaging man. From the time I was a child he was always teaching me - teaching me about horses, about farming, about Indigenous issues, about schooling, and so on. To this day he is teaching me and I'm so thankful for him. Thanks to him, I have been receiving teaching about Indigenous cultures for nearly my whole life. I always wanted to know more - I found it fascinating. We went to pow wows, I knew his family, we spend all major holidays together, we are deeply connected. My favourite tradition of mine is when my family goes out to their home every New Year's Eve to celebrate and after everyone else has gone to bed, my uncle and I sit up together and reflect on the year we leave behind, and what we hope for in the year ahead. Together, we see one cycle coming to an end and another one beginning. I am so grateful 
to my uncle because, without knowing it, he kept me and my dad involved in Indigenous community before any of us even knew that we were a part of it.

So I grew up in this place of love and support. My dad's cycle included pain, confusion, and isolation and so he left his home. But my cycle was love, acceptance, and support. And so I stayed. I stay with my family and because of this, I think we're able to have this new door open regarding our Indigenous heritage. My dad forging this new path brought us back to who we really are. We were coming out of dormancy. It was springtime.

\section{Identity Revealed}

This birth of our identity, this breathing of life into our identity came when an estranged member of my dad's family came to visit him. He told my dad that we had this ancestry and my dad was kind of surprised. Oh? Ok? And the immediate step after that was getting proof. How do you know? Show me proof. And his nephew had this card. The cardshowed that he was a valid member of the BAFN community and that he was enrolled under the Algonquins of Ontario (AOO) enrollment criteria, for the purpose of being consulted on the ongoing treaty. He had been given this card as proof of his ancestry and so that was the first step for both me and my dad. Get the card to prove that you belong.

The next time I went to visit my parents, my dad had told me about this conversation with his nephew. My dad told me that we had Indigenous ancestry and my reaction was a chuckle and a shrug. I found out later that my dad's interpretation of my reaction was that I didn't care. And I can certainly see why he'd think that. I've always been a person who remains stoic on the outside but can be battling absolute chaos inside. I'm so glad that he brought that up because I was able to tell him no, my reaction was the opposite of his interpretation. I laughed and chuckled because 
it was kind of like I knew it. I knew it. Finally. That was the laughter of relief of yeah, I knew it. And here it is. Hi.

\section{Proof}

So our first stop on this new journey was seeking proof - that colonial practice of 'show me on paper'. Show me on paper. Right? Show me on paper and they did. I'm registered with the Algonquins of Ontario. We contacted a woman with the Bonnechere Algonquin First Nation who was able to trace our Indigenous ancestry back through both my paternal grandparents. The process was fairly easy for us as my dad's other family members had already gone through the process and so the tracing had already been completed. So, we have the proof. We are non-status Algonquin Peoples. When the issue of status versus non-status arises, most people think of this in term of individuals and not of entire communities. Bonnechere Algonquin First Nation is, primarily, a non-status community. This is because

the British Crown never entered into formal treaty relations with the Algonquin and Nipissing, despite the fact that the Algonquin and Nipissing repeatedly petitioned British authorities to compensate them for the loss of their traditional lands and the destruction of the resources upon which they depended for their livelihood. (Holmes, 1998).

Holmes (1998), also describes how in 1873, the Golden Lake reserve was purchased for use by the Algonquins. Though they had not entered into any treaties, any Algonquin living on the reserve could now be considered status Indian under the Indian Act. Those Algonquins who did not live on the Golden Lake reserve were not officially recognized as Indians and so were not entitled to the many rights and benefits of those who had status. Myself and my dad belong to the non-status group. 
After receiving our proof of identity from our community my dad and I are both kind of on the same path. It is here that we intersect, again. We both found out about our ancestry around the same time. We got the proof. Government colonizer-style proof of identity and then we were both stuck with, "now what?" Now what? Because that piece of paper only takes you so far. It satisfies a piece of it but certainly not the whole. You're left with this vacuous space that needs to be filled with something but that piece of paper can't fill this whole space and so, now what do I do? So this is where my and my dad's paths branch off again. His went back into dormancy in a way - not entirely but for the most part, and I suppose mine did as well for a period of time. So I guess we both went back into dormancy. It was with schooling, ironically, that my Indigenous identity was confirmed and solidified.

\section{School/Community/Elder Support}

Here we've broken another cycle. Where my dad's path through school had broken and disconnected him from his identity, my path through school connected me to mine.

However, the difference here was that it was the Indigenous people within my school that helped this process along. As opposed to my dad's experience, there were no nuns and there were no priests telling me to change who I was. I had two professors who are of Indigenous ancestry - Lynn Lavallee and Cyndy Baskin. I had conversations with each of them separately and both were just immediately accepting. You're in. Come. There is so much for you to see. And, eventually, I was connected to the Aboriginal student services' office on campus.

As previously noted above, Ryerson University is named after a man with a long history of contributions to colonization and erasing Indigenous people. He created the residential school system where thousands of Indigenous children were stripped of their identities, given new names, and taught a new language. Sound familiar? The parallels between the residential schools 
and my dad's experience in French Catholic school is very similar. My dad even pointed this out during our conversations but was also quick to recognize that he didn't suffer nearly the caliber of atrocities that those in residential school went through. So now, here I was in Ryerson's namesake school embracing and diving into my Indigeneity. This resistance and resurgence within the school felt pretty good. It feels pretty good.

So I go into this office and I meet with Amanda Thompson, the academic adviser for Aboriginal students. Her title doesn't at all capture the magnitude of what she does because, yes, she certainly gave me academic resources, but she also gave me this sense of profound belonging in that space. I was never doubted, never questioned, never asked to quantify myself when I sat in her office. She was immediately accepting and toured me around showing me all the resources and supports that were available to me as an Indigenous student. I walked out of that space so peaceful and full. That vacuous space that was left after receiving my paper proof of Indigenous ancestry was now filled. And it was beautiful. Amanda connected me to the campus Elder, Joanne Dallaire, who I had been trying to connect to for so long without success. Joanne is not on campus every day of the week and, when she is, she's often asked to take part in different events across campus. Getting in touch was very difficult. As far as travelling a path, meeting with Joanne was the path I was trying to get on first and it just wasn't working. But I got to her and I later learned through her that everything happens for reason and in its own time. I really felt that. I really felt that because without the other people who I met and spoke with first, I would have missed connecting to the community. I would have missed all these little validations and welcomings of support. I would have missed it all and so I am able to see now that the path I took was the right one. 
Once I met with Joanne, the Elder, the floodgates opened. I was out. I was out, and simultaneously, I was in. I was in this community. And it was in the first meeting I had with her, my spirits talked to her. They were ready. My spirits shouted, "It's about time! Here you are! We have so much to tell you". Joanne said some people come to her and they're ready for their name, their colours, and their clan, but some people aren't ready. She let me know that I was ready. And so we did ceremony and she taught me about it because I didn't know. I didn't know what ceremony was or what it looked like or why certain things were done and so she taught me. She taught me about my own traditions that I had no idea about. She taught me with a gentleness while explaining how colonization has separated so many Indigenous people from their traditions, and that I was not the only one who felt so disconnected.

During our ceremony, I was given my name and my clan and my colours and that vacuous space that was previously filled by Amanda now grew wings. It grew something entirely new. I found out in that meeting that I am golden eagle clan and I really truly feel like I grew wings that day. I told Joanne that previous to talking with her and the other Indigenous people I had met on campus, I felt like I was floating around in space belonging nowhere and to no one. But after this ceremony and being given my spirit name, I walked out of that office and I felt like I had just launched - just spread my wings and was free. I felt free. I stopped the free-fall of floating in an abyss of missing identity and I learned to use my wings, to gain control of them and find direction. Even my spirit name, which I keep to myself and a small group of people, represents beginnings, creation, and the start of something new. And while it was something new to me at the time, it was also something very old, very sacred, and had been locked away for a very long time. Now, it had a name. 
Though my dad has yet to receive his spirit name, clan, and colours, he told a story in one of our conversations about a made-up clan that he was indoctrinated into when he was younger. When he lived in Brantford, Ontario, he was good friends with a neighbour who was originally from Six Nations. My dad's friend told him that he belonged to the turtle clan and my dad thought that was pretty great. He said to his friend, "You've got a clan, what the hell do I belong to?" and his friend turned to him and said, "You're a frog for god's sake, you're French". My dad says they had a good laugh about it and his friend brought him to Six Nations to a silversmith who made him a frog ring that he still has to this day.

In our storytelling conversations, my dad said, "Yeah, that's the closest I got to being in a clan was the clan of one". To my knowledge, a frog clan doesn't exist in Indigenous communities in Ontario, and so he felt a part of a community despite being the sole member of the frog clan. The next thing he said I think will stay with me forever; he told his friend in that moment that, "We're in the same pond, me [the frog] and the turtle". And he is right. We're all one. And this is the significance of the medicine wheel teachings; everything is connected.

\section{Research Journey}

I then began my formal academic research journey of examining Indigenous identity and this is where my and my dad's paths intersect again. His journey continued to lay dormant for a few years after we had found out about our ancestry and here I am to bring it up again - for the purpose of academic credentials. It isn't done. I asked my father: Do you want to do this with me? Do you want to get into this? Tell some stories? Start this journey together? And he did and so we met. We met on two separate occasions to talk. I had no set questions I just had ideas of what I wanted to talk about such as finding out about our ancestry, what he wanted to do with the information, and if he remembered any time in his past where his ancestry was spoken about. 
And we talked about those things but they came about in a natural way in the conversations. We talked about our spirits, our emotions, our bodies, and our minds - all four quadrants of the medicine wheel presented themselves. And it was so transformative to sit and listen to my dad tells stories, some of which I've heard before and others I hadn't. And I listened to him talk in a way that was so eloquent and thoughtful and symbolic. I'm not even sure he realized it at the time, but it was extraordinarily profound.

There were many themes in the conversations, but the one thing that really stood out to me that I shared along the way with him was this need to "find a direction", this need to be "in the circle". It kept coming up. And here arises the symbology of the medicine wheel again - this circular wheel that highlights north, south, east, and west - each direction with a different teaching. There was a period of feeling paralyzed after we found out about our ancestry that we both shared. We want to be a part of our nation, our community, but we've been so removed and we're so detached from tradition. What if they don't accept us? And I come to find out, actually I think my dad and I come to find it out together - that we were always in that circle. This was another theme that came up in our conversation, the strongest theme. The topic that we talked about the most was the sense of knowing, this sense of questioning if there was something missing in our lives and a sense of connection with Indigeneity. But then just as quickly as the questioning came up for both of us, we quickly dismissed it because we didn't have the proof. This colonial practice of 'proof' is so deeply entrenched and becomes really clear when in one of our conversations my dad said "I just want to know. I just want to know. It's just something I've always wanted to know. [I] felt it and never knew why”. Don't get me wrong, I understand the need for proof of identity, particularly when claiming to be part of the Indigenous community that has, for generations, been abused and exploited. The problem of proof arises when one type 
of proof is privileged over another, for example, the Indian Act being the primary method by which to qualify someone as an Indigenous person rather than members of their community making this decision. It leaves me to also wonder where instinctual knowing lies on the spectrum of Indigenous identity and belonging. We've been conditioned, by tactics of violence and oppression, to need paper proof of our belonging. But what about a person's spiritual connections and sensing that can't be quantified? There is a very difficult balance of honouring Indigenous ways of knowing and belonging while simultaneously protecting the community from imposters. But this sense of knowing for both myself and my dad was so strong. It was really present in our conversations and felt so deeply by us both.

During our conversations on separate weeks where we sat at my parents' kitchen table and talked, both times these bunnies would appear on the front lawn of their home, and it did not go unnoticed by me. I got excited because I knew it had meaning. There they were playing in the front yard together the two of them and there's usually only one. If we ever see a bunny in my parents' neighborhood, it's only one, and in this moment during our conversations there were two. They stuck around for a bit on the front lawn in our view and at the time I had no idea what it meant but I knew it was something. Here we are, me and my dad, and there they are, two bunnies presenting themselves to us on two separate occasions. I knew it meant something that I couldn't put together at the time but I see now.

When I reflect on what rabbits mean to me all I can think of is how they appear in the springtime. You see them at a time when things are starting to grow, come back to life, and regenerate and there they were in this conversation that me and my dad were having and it was beautiful. The world speaks to you. The world has always spoken to me and my dad. It's always given us these indicators, these messages, these signs that help to guide and comfort us but we 
just never knew what to look for. We were never taught that we had spirits that would guide us through animals and nature. We were never taught that we would be supported by our environment and that we had the same responsibility to care for the environment as well. And now I've been taught and so I can make sense of the cues that I'm given and my dad is on his way to getting there himself.

\section{Finding Peace}

Nearing the end of our last conversation, my dad shared how he hoped this journey would give him a sense of peace he never felt he had. He talked about how he can appear very calm on the outside, but on the inside he'd been ripping himself apart. I challenged him and said that he doesn't appear as outwardly calm as he may think that he does. We kind of laughed. I shared with him that I'm very much similar to him - sensitive, quick to anger, and existing on two ends of a spectrum with one end being really quiet and the other end being really loud. He said that this is something he's wrestled with his whole life and he said, "it's because I've been fighting myself". To me, this sums up this whole journey to Indigenous identity. You're told by others all your life that you're someone you're not. Change your name, change your language, change your beliefs, and you do your best to change those things but inside you're slowly dying. Your spirit is suffering and you do your best to silence it. It's a losing battle, though. It can't be silenced but my god do you try. This journey for me has created that peace that my dad is still seeking but he's on his way. He talked about it not in terms of peace of mind but inner peace when he said, "Okay, I’ve found myself, now I can just calm down".

Of course, this journey has not been a linear one. It's not just a matter of the truth being revealed, connecting with community, and then being at peace. No, it's not this simple. There are a whole range of emotions that myself and my dad are left to deal with on the journey 
to Indigenous identity. For me, grief and sadness have been ever present along my path. As I have mentioned before, I am a fairly quiet person who doesn't show much emotion to outsiders. What I have found, however, is that since I have started this journey and find myself attending more ceremonies, I cannot stop the tears from pouring down my face. I would say the dominant feeling that comes up for me is being overwhelmed - I feel so much grief for all the years that I've been separated from this community and simultaneously, I feel immense gratitude for finally finding my way back. It's a roller coaster. In addition to all these feelings going on, I'm left wondering if I even fit in at all. Is it okay for me to be here? Do I have a right? Do I look 'Native' enough? The internal colonial dialogue is a powerful force. I'd be lying if I said I've completely silenced it. It is deeply entrenched. It's a little voice telling you that you're not Indigenous enough; the bloodline is too distant; your features don't all match the essentialized idea of what an Indigenous person is supposed to look like. We colonize ourselves every day without even realizing it. This has been a real challenge for me in this process. I act as a colonizer to myself every single day, verbally and emotionally destroying my right to be an Indigenous woman. It is in community that I have found acceptance and an understanding of how colonization continues to strip away a person's right to align with their community. What has brought me the most comfort in this process is the community - an ever present theme in these conversations with my dad.

\section{Back to Community}

In our conversations, my dad spoke about the importance of connecting with community, of recognizing how much it's done for me in my community at school and how whenever I talk about it he says he's “all ears". He loves to hear about what I'm learning and he's fascinated. And so he's recognizing that this is his time now to do the same and he has a plan for who he's 
going to speak to - an Elder in his community in London whom he knows. He is a neighbour whom he has spoken to many times before and from whom he's been given a sacred medicine sweetgrass. So that's where he's going to start, kind of where I did as well - with an Elder.

\section{The Returning}

My dad has shared with me during our conversations that he's hoping to return to Pembroke, his birth place, this coming summer to attend some special gatherings of our Algonquin nation. I felt very surprised by this as my dad rarely has returned with the exception of his parents' funerals, the last one over fifteen years ago. He said, "I really didn't want to go back but now that has changed with finding this out". This is the power of finding out your identity - you want to connect back to where you came from, to return to yourself.

So, things come back around in the circle. My dad gave me life; he gave me a loving, safe, comfortable, cared-for life that I am so grateful for. My hope is that this project, the path that I've been walking and asked him to join me on can now give life back to him. I've found my direction because of his example, and he will find his direction because of mine. One feeds the other.

This is my creation story. I was born at 32 years old as an Algonquin, golden eagle woman. There's so much more to learn and so much more to know and this is just the beginning; the spring; the east; the bunny. 


\section{Chapter 5: Look to the Medicine Wheel}

The medicine wheel teaches us that all of life is interconnected. Everything on earth has a spirit, everything on earth depends on each other -we're all in a relationship. The medicine wheel also teaches us that life happens in a series of cycles and patterns. These things are inevitable just like the sun rises and sets in the same place each day - just as the seasons change from spring, to summer, to fall, and then winter. There are things that we can expect to be inevitable in our lives. There are also patterns and cycles that do not need to remain steady, and, in fact, are important to actively attempt to change.

In these conversations with my dad what seems to be ever-present is this need to find a direction. Both of us have wondered: Where do I go? What do I do? Who do I talk to? Instead of feeling like we're on a path that forks in one or two ways, the path we've found ourselves on, in pursuing our Indigenous identities, is a path that can turn into a multitude of different directions each leading some place different. My dad and I have certainly travelled on differing paths that have sent us in different directions. We've both taken different paths. Sometimes they've intersected and sometimes they've been separate but we both find ourselves in the same place in the end - back around the circle to ourselves. And that's been the direction that we've both been seeking this whole time - a circle. The direction we seek is not a straight line, or a zig zagged trail, or a curved path, it is a circle. We're hoping to belong to the earth and our people. Everything and everyone in the circle has a name, a place, a role to fulfill in the relationship. But what happens when you don't have a name? Or you don't have a role? Or there's this feeling that something is missing? Having a name is paramount to the function of the circle. When this is taken away or hidden from you there is a disconnect and so you no longer feel a part of that 
circle. This was what was so powerful about being given my spirit name and clan. I now had a role to serve in my community and a name that let others know who I am. I now have a purpose. What I've come to know in conversations with my dad is that we have always been in the circle - it's in our blood. Indigenous scholars have written about the spiritual connections and ties Indigenous people have to their ancestors and their histories. Robin Wall Kimmerer (2013) writes about smelling fresh sweetgrass and when you "breathe it in $[\ldots]$ you start to remember things you didn't know you had forgotten” (p. ix). Onowa McIvor (2010) quotes the great scholar Lionel Kinunwa who said

our ancestral memories are in your blood, they are in your muscles, they're in your bones, they're in your hair...that is why when we hear the drum, our spirit is moved. The vibrations of the drum stir old memories - our ancestral memories (p.143). I remember as a young child being brought to a pow wow for the first time. I was walking up to the event with my family as the drummers began to drum and my whole body reacted in a very visceral way. From head to toe I became tingly as if invigorated and I couldn't prevent the tears from welling up in my eyes. I honestly feel that in that moment, I had been awakened. The sound of the drum and the singing felt so familiar, so comforting, and made me feel as though I was deeply grounded. As Absolon (2011) says our ancestral ties and our spiritual ties are so strong that even if a person has just a drop of indigenous ancestry there's still a bloodline and spirit connection and that spirit might find its voice through that person somehow in some way. (p. 60)

And I feel that this has been our story. Our bloodline is so strong and our ancestors and spirits are eager to help, guide, and protect us in our travels as we make our way back around the circle. 
What my dad has done in his life is changed some cycles and stepped out of some harmful and abusive patterns. As soon as he could leave Pembroke he left. He was done. And even in his exit there was an expectation that he choose one of two options, and he ended up choosing neither; he made a new path for himself. And on this new path, he walked into his new workplace and changed their pattern too. My dad has broken so many cycles in his life that perpetuated assimilation, abuse, and silence. These are things that he grew up with and these were things that were expected of him but he chose not to continue these cycles. And in this choosing, he forged this new path for himself and ultimately for me. He stopped those cycles of abuse and pain.

I never experienced any of those things to the same degree that he did. As I've said before, I grew up in love, support, encouragement, and freedom because of my dad and the patterns that he stepped away from. And I think this is an important lesson: that though some patterns and cycles are fixed and unchanging like the sun rising and setting in the same directions each day there are things that do need to evolve and change. Where there is imbalance, balance must be restored. This can be said not just in terms of people, but also within cultures. People can choose to change and this is what my dad did - he restored the balance. Little Bear (2000) says that "the function of Aboriginal values and customs is to maintain their relationships that hold creation together. If creation manifests itself in terms of cyclical patterns and repetitions, then the maintenance and renewal of those patterns is all important" (p.81). Because of colonization, the cycles and patterns that held our connection to our Indigenous stories and teachings had been brutally damaged. We had unwillingly been ripped away from our community. My dad reconnected himself to the circle that had previously been broken. He changed the cycle of erasure and brought us back together. When our people were ripped out of 
the circle through colonization and violence this was passed down through generations. Family, traditions, and teachings were silenced and punished and never spoken about and this created a divide. What my dad did was repair the circle and though he wasn't conscious of it at the time what he was creating was an Indigenous rebirth.

My dad has been transforming pain for his entire life without really knowing how significant this would be in our lives. I don't believe he ever really saw it this way either - never gave it a name. But now it has its name-Indigenous resistance, resurgence, and resilience. And here we are because of him back in the circle, back with a name, back in community, and back to ourselves.

Historically, research in Indigenous communities has been harmful, colonizing, and painful. In this research process there has been healing and connection and strength. This is where I'm beginning the process of breaking old and damaging patterns myself. Where my dad experienced pain, isolation, and erasure in school, for me, it has become a place where my Indigenous identity has been born. School has been the gateway to re-righting my family's past and finding our place within community. Where research on Indigenous Peoples in the past has acted as another tool of colonization, this research project has been a process of decolonization. Absolon (2011) says that "in a sense, healing is woven throughout the re-search process. Indigenous research becomes a healing journey when what we gather helps us to recover and heal a part of our self, life, family, community, knowledge, culture, language and so on" (p.93). Jean Paul Restoule (2000) encourages people not to use the term 'identity' and instead use the term 'identifying' when defining oneself. He speaks about how the colonizers who created measures of defining Indigenous People through the Indian Act and other assimilating policies, have given themselves the privilege of being able to change their culture with time and allowing 
for it to evolve, as all things do. However, the varying Indigenous cultures ways of life aren't afforded that same privilege and they are expected to stay in this essentialized way of being. They are expected to remain fixed and not fluid. Restoule (2000) says "identifying is a process of being and becoming what one is in the moment" (p. 103). He recognizes that who we are right now, will not always remain the same. As I've mentioned before, this is the story of my reality at this moment of my life - I very much expect that things will change with time. How else am I expected to learn and grow?

So the goal of this project was to find a place of identity, it was to find a place of belonging. I want to get to know who I am and I want my dad to do the same. In my mind, the goal for this process was met the moment that he and I came together and spoke life back into our history. This was the first time we had talked about these things and we explored it together. Resurgence and revival had already begun. Our identifying had already started. And there is no end of identifying - it goes on around the circle.

In her book, Braiding Sweetgrass - Indigenous Wisdom, Scientific Knowledge, and the Teachings of Plants, Robin Wall Kimmerer (2013) talks about one of our sacred medicines - sweetgrass. She describes how the goal is to tightly braid the sweetgrass so that it's worthy of giving away and serving its healing purpose. She speaks about the difference between doing this alone and doing this with the help of someone else. I feel the following quotation from her book is a perfect way of summarizing this research process I've undertaken with my dad:

but the sweetest way is to have someone else hold the end so that you can pull gently against each other, all the while, leaning in, head to head, chatting and laughing, watching each others hands, one holding steady while the other shifts the slim bundles over one 
another, each in its turn. Linked by sweetgrass, there is reciprocity between you, linked by sweetgrass, the holder as vital as the braider (Wall Kimmerer, 2013, p. ix)

Coming together in this journey has allowed me and my dad to strengthen our relationship with each other while simultaneously strengthening our relationship to our roots. When one has been unsure, the other has helped to guide. We each have our own way of travelling our separate paths, but we also join together to strengthen and face our ultimate goal. 


\section{Chapter 6: Conclusion}

I think one of the challenges for me and my dad that seemed to come up repeatedly in our conversations was this feeling of removal and disconnect from this circle, the Indigenous circle that we wished to be a part of so desperately was that we felt completely out of it, completely removed, completely unaware, and we were nervous to enter into the circle for fear of rejection and judgement. Fear. There was so much fear. What I think we both ended up finding out is that we've been a part of this circle for our whole lives but we just never knew. We lived in such a way that was Indigenous. It is Indigenous. But it was never named as such. It never had a name. There were all these indicators telling us who we were as Indigenous people but we just never paid them much attention. I was always told and continue to be told by my friends that I'm a great storyteller, strangers would ask me if I was an Indigenous woman, I was born with this jet black hair, and I had this spirituality that I didn't necessarily understand but I felt. I always found great comfort in the company of other Indigenous people and I would experience feelings of profound grief in those moments, as well. Powerful connection and profound grief. I mostly judged myself for being so moved by the community. Why on earth are you crying at this pow wow, and why are you crying with these women drummers? I just never knew. And now I do. Now I understand. I've always been a part of the circle. And now I know. I feel it. And I've been welcomed. And now there's nowhere to go but forward - back around the circle again with no expectations but an open heart and a grounded sense that I belong.

This journey makes me think of a newborn baby coming into the world. This new baby is born seemingly helpless and needs to be cared for diligently while it slowly develops into an independent person. As a newborn, it has many mountains to climb and much to learn. So often we think of a baby as a helpless little creature but we forget that it has this natural way of 
keeping itself alive - of supporting itself. Instinctual behaviours are rooted in the baby that are practiced from birth such as suckling and crying when it needs to be attended to. This is done independently and without previous training. This is how I see myself and my dad coming into our Indigenous identities. There is so much that we need to learn and so much that we have missed out on having been disconnected from our heritage for so long. However, there are these deeply ingrained ways of being and ways of knowing that have come naturally to us that we've practised over time which have kept us alive. These ancestral and spiritual supports have sustained us. We have both felt a connection to Indigeneity our whole lives. We always were questioning who we were, and wondered where we belonged. There was always a knowing but coupled with this knowing a quick silencing and dismissal of our curiosity. And this silencing didn't come from other people, it came from within. We silenced ourselves. Well, that silencing is now over.

This whole process, particularly the journey of writing my research paper process, has been transformative. It brings to mind a quote from Lee Maracle (1996) where she shares that anything that brings people closer to themselves is a ceremony. The search for the truth of one's spirit is a private one, rich in ceremony. The manner in which a person seeks the self is always based on the sacred right of choice. (p.111).

Though this paper was done in the pursuit of academic qualifications it's been so much more than that for me. This is my resurgence and an opportunity to learn about myself and I hope that it's been this way for my dad as well. This process has also been a reclamation. At the beginning of this paper, I discussed how I don't like to use the term 'settler' because it implies that the Indigenous land and peoples were not settled previous to colonizers' arrival. The truth of the matter is, Indigenous Peoples were very settled in their land and, ironically, it was these 
colonizing settlers who arrived and created the pain, chaos, and imbalance that is still present in the lives of many Indigenous Peoples today. Battles and war were not necessarily new to the Indigenous Peoples as they had fought many amongst each other prior to the Europeans arriving however, it was the Europeans who birthed a different kind of a battle for Indigenous Peoples colonization. (Lawrence, 2012). It is a near-constant internal battle of the self. A fight to keep one's history alive. A fight to connect back to what was stolen. It feels like a constant battle.

My dream for this project was for me and my dad to find some peace and a place to belong - to speak life back into our ancestors and our histories. My dad shared that he thought this journey would help him to finally find a sense of inner peace so he can stop battling himself. I, too, share in this hope. And this, in the end, is how we become a settled people.

Walking this path to Indigenous identity formation alongside my dad has taught me many things, but what stands out most is this: You may each choose a different path to walk down to find your answers, there is no right or wrong. You are guided to what you need to know. In the end though, no matter what path you may choose, you will find that your path has led you in a circle leading right back to yourself. The answers lie within. What you are seeking is you, and so you come back home to yourself. 


\section{Appendix A}

\section{Ryerson University Consent Agreement}

You are being invited to participate in a research study. Please read this consent form so that you understand what your participation will involve. Before you consent to participate, please ask any questions to be sure you understand what your participation will involve.

\section{Pathways to Indigenous Identity: One Family's Story of Colonization and Reintegration}

INVESTIGATORS: This research study is being done by Shanna Giroux, a Masters of Social Work (MSW) student from Ryerson University and it is being supervised by Susan Preston, associate professor, from the School of Social Work at Ryerson University.

If you have any questions or concerns about the research, please feel free to contact Shanna Giroux at shanna.giroux@ ryerson.ca or Susan Preston at susan.preston@ ryerson.ca or 416-979$5000 \times 6218$.

PURPOSE OF THE STUDY: This research study is designed to help explore what it means to be an Indigenous person to Canada. It will examine how the knowledge of Indigenous family ancestry has come to be erased after generations of violence and colonization using your family as an example. General topics to be discussed will include: memories from childhood of Indigenous traditions/knowledge, reactions to finding out you have Indigenous ancestry, and what, if any, plans you have of involving yourself in the Indigenous community.

The participants in this study will be you and the principal researcher discussing your shared family history. All other persons will not be invited to participate for the purposes of this research project.

This research is being conducted for the purposes of fulfilling the Major Research Paper (MRP) requirement of the MSW program. The research findings contained within the MRP will be included in the Ryerson Library system making it available to all Ryerson students and staff. The research findings may be published in the future or used in future research projects (journal publications, case conferences and presentations) by the principal investigator.

WHAT YOU WILL BE ASKED TO DO: If you volunteer to participate in this study, you will be asked to do the following things:

- Review and sign the consent form before the research project beginning

- Participate in two, one-hour audiotaped discussions located in your private home with the principal investigator

- Review archival materials such as birth records, marriage/death certificates, etc. for the purposes of lineage tracing. 
- Meet with principal investigator after the data has been collected/discussions have occurred to review data and approve of or remove what will be discussed in the research at all stages up to its submission.

- Ask to erase information that you are not comfortable with being included in the research

\section{POTENTIAL BENEFITS:}

I cannot guarantee that you will receive any benefits from participating in this study.

WHAT ARE THE POTENTIAL RISKS TO YOU AS A PARTICIPANT: If you volunteer to be a participant in this study, there may be potential risks for you that are minimal.

There may be questions or topics that come up that upset you emotionally or mentally. Please know that you are welcome to pass on any topic or question that comes up in conversation if it causes you discomfort in any way. You will also be provided with a list of local resources to go to for emotional support should any issues come up during the research project.

Also, due to the nature of this research project, your privacy cannot be protected and your name will be published within this MRP and in any future publications to do with this study. Prior to any future publications or presentations of this study, you will be contacted first to ask for permission to submit or participate in that project using your information. If this causes stress or discomfort, please know that you can withdraw from the project at any point up to the point of data analysis. Please note, that you will be consulted by the principal researcher and allowed to review and revise (add or remove content) in her research paper at all stages prior to its submission. The researcher can continue on with the research without your participation if you decide to withdraw.

If you choose to withdraw from the research project at any time, please know that the principal researcher can carry on with the project using only her own stories/experiences and will make no reference to any of your own stories as the former participant. If the principal researcher is to make reference to you in her MRP it will be in generic terms such as 'a paternal relative' to ensure your identity is kept confidential. Your name, your stories, and your identifying information will not be used in the final MRP if you choose to withdraw. To ensure this is to your satisfaction, the principal researcher will provide you with a copy of the finished MRP prior to submission for your review to be sure that you are satisfied that your identity has been protected. Any addition or deletion requests you make at this time will be honoured.

There is also a conflict of interest within the research project as the principal investigator is your daughter. Please understand that you are under no obligation to participate in this research project as it can continue without your participation with no impact on the existing relationship.

CONFIDENTIALITY: The research data for this project will be collected via review of archival materials (i.e. birth/marriage/death certificates) and audio-recording at the time of each meeting between you and the principal investigator. You will be involved in each step of the data collection and distribution including reviewing the recordings, review the research paper as it is 
being written, and comment or request additions or deletions to your stories. Your involvement throughout the research project is a component of Indigenous research methodology and allows you to have some control over what is shared.

The data that will be collected is a signed consent form, audiotaped recordings of storytelling conversations, and transcripts of these conversations.

All digital data will be stored electronically in the principal investigator's password protected computer as well as on a password-protected USB key. Signed consent forms will be kept in a secured drawer in the researcher's home accessed only with a key.

Due to the nature of the research project being based in Indigenous storytelling methods, and the research including specific family experiences and history, your confidentiality/privacy cannot be ensured. At any point in this process if you decide that you are no longer comfortable with your name being made public for the purposes of this study up to the point of data analysis, you may withdraw your participation. Again, you will be notified at the time of data analysis to confirm your continued interest in the study.

Audio files will be deleted after the transcriptions of the conversations between you and the principal investigator are completed which is anticipated to be within two to three weeks of each meeting.

Transcriptions will be stored on a password protected USB for seven years as the principal researcher may use this data for future research projects such as journal publications, case conferences, presentations, and other publications.

The principal researcher will be meeting regularly with the campus Elder, Joanne Dallaire, for consultation and support of this research project. Her role is to ensure cultural accuracy and practice. Joanne Dallaire will be aware of your identity and she will have access to the data that is collected through the meetings you have with the principal investigator.

INCENTIVES FOR PARTICIPATION: There will be no financial payment or other incentive for your participation in this study.

COSTS TO PARTICIPATION: There will be no cost to you as a participant as the researcher will meet you at your home and does not require you to travel. If there is occasion for you to contact Joanne Dallaire, the campus elder, to ask any questions, her contact information will be provided to you.

COMPENSATION FOR INJURY: By agreeing to participate in this research, you are not giving up or waiving any legal right in the event that you are harmed during the research.

VOLUNTARY PARTICIPATION AND WITHDRAWAL: Participation in this study is completely voluntary. You can choose whether to be in this study or not. If any question makes you uncomfortable, you can skip that question. You may stop participating at any time up to the point of data analysis and you will still be given the incentives and reimbursements described 
above. The principal researcher will let you know at what time she will be doing data analysis so that you may decide at that point if you are still interested in participating. If you choose to stop participating, you may also choose to not have your data included in the study. Your choice of whether or not to participate will not influence your future relations with Ryerson University or the investigators [Shanna Giroux and Susan Preston] involved in the research.

QUESTIONS ABOUT THE STUDY: If you have any questions about the research now, please ask. If you have questions later about the research, you may contact.

Shanna Giroux

Primary Investigator

shanna.giroux@ryerson.ca

Susan Preston

Supervisor

susan.preston@ryerson.ca

4169795000 ext. 6218

EPH 221, Eric Palin Hall

This study has been reviewed by the Ryerson University Research Ethics Board. If you have questions regarding your rights as a participant in this study please contact:

Research Ethics Board

c/o Office of the Vice President, Research and Innovation

Ryerson University

350 Victoria Street

Toronto, ON M5B 2K3

416-979-5042

rebchair@ryerson.ca 


\section{Pathways to Indigenous Identity: One Family's Story of Colonization and Reintegration}

\section{CONFIRMATION OF AGREEMENT:}

Your signature below indicates that you have read the information in this agreement and have had a chance to ask any questions you have about the study. Your signature also indicates that you agree to participate in the study and have been told that you can change your mind and withdraw your consent to participate at any time. You have been given a copy of this agreement. You have been told that by signing this consent agreement you are not giving up any of your legal rights.

Name of Participant (please print)

Signature of Participant

Date

I agree to be audio-recorded for the purposes of this study. I understand how these recordings will be stored and destroyed.

Signature of Participant

Date

I wish to have a pseudonym used in the dissemination of this study to protect my identity.

Signature of Participant

Date 


\section{References}

Absolon, K. (2011). Kaandosswin: How we come to know. Halifax, NS: Fernwood Publishing.

Absolon, K., \& Willett, C. (2004). Aboriginal research: Berry picking and hunting in the 21 st century. First Peoples Child \& Family Review,1(1), 5-17.

Alfred, T. (2009). First Nation Perspective on Political Identity. Ottawa, ON. Retrieved from: http://firstnationcitizenship.afn.ca/uploads/A1_First_Nation_Perspectives_on_Political_I dentity.pdf

Alfred, T., \& Corntassel, J. (2005). Being I: Resurgences against contemporary colonialism. Government and Opposition, 40(4), 597-614.

Allen, C. (1999). Blood (and) memory. American Literature, 71(1), 93-116.

Baskin, C. (2005). Storytelling circles: Reflections of Aboriginal protocols in research. Canadian Social Work Review/Revue Canadienne de Service Social, 22(2), 171-187.

Berry, J. W. (1999). Aboriginal cultural identity. Canadian Journal of Native Studies, 19(1), 136.

Canadian Institutes of Health Research, Natural Sciences and Engineering Research Council of Canada, and Social Sciences and Humanities Research Council of Canada, Tri-Council Policy Statement: Ethical Conduct for Research Involving Humans, December 2014

Castellano, M. B. (2004). Ethics of A research. International Journal of Indigenous Health, 1(1), 98-114.

Kimmerer, R.W. (2013). Braiding sweetgrass: Indigenous wisdom, scientific knowledge, and the teachings of plants. Canada: Milkweed Editions.

Lawrence, B. (2003). Gender, race, and the regulation of native identity in Canada and the United States: An overview. Hypatia,18(2), 3-31. 
Lawrence, B. (2012). Fractured homeland: Federal recognition and Algonquin identity in Ontario. Vancouver, BC: UBC Press.

Lawrence, B., \& Dua, E. (2005). Decolonizing antiracism. Social Justice,32(4), 120-143.

Little Bear, L. (2000). Jagged worldviews colliding. In M. Battiste (Ed.) Reclaiming indigenous voice and vision (pp. 77-85). Vancouver, BC: UBC Press.

Macdougall, B. (2012). The myth of Métis cultural ambivalence. In C. St-Onge, B. Podruchny, \& B. Macdougall (Eds.), Contours of a people : Metis family, mobility, and history (pp. 422-464). Norman, OK: University of Oklahoma Press.

Maracle, L. (1996). I am woman: A native perspective on sociology and feminism. Toronto, ON: RaincoastPress

McIvor, O. (2010). I am my subject: Blending Indigenous research methodology and autoethnography through integrity-based, spirit-based research. Canadian Journal of Native Education, 33(1), 137-155.

Métis Nation of Ontario (n. d.) Who are the Métis. Retrieved from http://www.metisnation.org/culture-heritage/who-are-the-m\%C3\%A9tis/

Naumann, D. (2008). Aboriginal women in Canada: On the choice to renounce or reclaim Aboriginal identity. The Canadian Journal of Native Studies, 28(2), 343-361.

Porsanger, J. (2004). An essay about Indigenous methodology. Nordlit, 8(1), 105-120.

Reed-Danahay, D. (Ed.). (1997). Autolethnograpy: Rewriting the self and the social. Oxford, England: Berg.

Restoule, J. P. (2000). Aboriginal identity: The need for historical and contextual perspectives. Canadian Journal of Native Education, 24(2), 102-112. 
Richardson, C. (2004). Métis identity creation and tactical responses to oppression and racism. Variegations, 2, 56-71.

Ryerson, E. (1847). Report $n$ a system of public elementary instruction for Upper Canada. Montreal, QC: Lovell and Gibson. Retrieved from https://archive.org/details/reportonsystemof00ryeruoft

Sawchuck, J. (2016). Negotiating an identity : Métis political organizations, the Canadian government, and competing concepts of Aboriginality. The American Indian Quarterly, 25(1), 73-92.

Smith, L. T. (1999). Decolonizing methodologies: Research and indigenous peoples. London, England: Zed Books Ltd.

Smith, L. T. (2012). Decolonizing methodologies: Research and indigenous peoples (2nd ed.). London, England: Zed Books Ltd.

Thomas, R. (2005). Honouring the oral traditions of my ancestors through storytelling. In L. Brown \& S. Strega (Eds.), Research as resistance: Critical, Indigenous, and antioppressive approaches (pp. 237-254). Toronto, ON: Canadian Scholars Press.

Turner, T. (2010). Researching Metis identity: My Metis family story. (Unpublished doctoral dissertation). University of Saskatchewan, Saskatoon.

Weber-Pillwax, C. (2003). Identity formation and consciousness with reference to northern Alberta Cree and Metis Indigenous peoples. (Unpublished doctoral dissertation). University of Alberta, Edmonton.

Wilson, S. (2008). Research is ceremony: Indigenous research methods. Winnipeg, MB: Fernwood Publishing. 
Yellow Bird, M. (1999). What we want to be called: Indigenous peoples' perspectives on racial and ethnic identity labels. American Indian Quarterly, 23(2), 1-21. 